\title{
The Effect of Investment Materials on the Color of Feldspathic Ceramics
}

\author{
Gloria Beatriz de Azevedo Cubas ${ }^{a}$ \\ Sílvia Terra Fontes ${ }^{a}$ \\ Guilherme Brião Camachob \\ Flávio Fernando Demarcob \\ Tatiana Pereira-Cencib
}

\section{ABSTRACT}

Objectives: The aim of this study was to evaluate the influence of investment type on the color of feldspathic ceramics.

Methods: Ceramic specimens were constructed using the refractory die technique, using four investments (i.e., Vitadurvest, Duravest, Duceralay Superfit, and Fortune) to observe their effect on the color of five commercially available ceramics (i.e., Super Porcelain EX-3, Vision Esthetic, Vintage Halo, IPS Classic, and Vitadur Alpha). The color analysis of the ceramics was performed with a colorimeter using the CIE L*a*b* color coordinates.

Results: The investments produced significant alterations on $a^{*}, b^{*}$, and $L^{*}$ color parameters of the ceramics tested. The ceramic Vision Esthetic was influenced by the type of investment in all color parameters $(P<.05)$. Two investments (Duravest and Fortune) produced alterations in color parameters with three of the five ceramics tested.

Conclusions: The investment materials produced alterations on the ceramic color parameters, resulting in unacceptable chromatic alterations ( $\Delta E^{*}$ ). (Eur J Dent 2011;5:433-440)

Key words: Investment; Ceramic, Color.

- a Graduate Student, Department of Restorative Dentistry, School of Dentistry, Federal University of Pelotas, Brazil.

b Associate Professor, Department of Restorative Dentistry, School of Dentistry, Federal University of Pelotas, Brazil.

- Corresponding author: Tatiana Pereira-Cenci School of Dentistry, Federal University of Pelotas Rua Gonçalves Chaves, 457, 2nd floor

Pelotas - RS - Brazil 96015560

Phone/fax: +55 5332226690

E-mail: tatiana.cencidufpel.tche.br

\section{INTRODUCTION}

The esthetic demand for restorative treatments that reestablish natural teeth's aspects is a major concern in Dentistry. ${ }^{1}$ Among the available options, ceramic restorations are an excellent alternative because of advantages, such as aesthetic, biocompatibility, chemical durability, fluorescence, compression and wear resistance, and thermal expansion coefficient similar to the dental structure. ${ }^{2-5}$ Advances in resin-based ce- 
ments and adhesive systems technology allowed the increase of clinical applications of all-ceramic restorations. 6,7

Replicating the appearance of natural tooth structure requires careful control of the form, surface texture, translucency, and color of the restoration. ${ }^{8}$ Laboratory procedures that involve ceramic brand and batches, ${ }^{8-10}$ ceramic firing temperature and number of firings, and the condensation technique $\mathrm{e}^{11-13}$ also could affect the final shade of the porcelain. Therefore, the color of the ceramic chosen may not correspond to the exact color of the tooth. ${ }^{14}$

Laboratory procedures involved in the construction of porcelain inlays, onlays, all-ceramic crowns, and veneer restorations demand the use of refractory dies of dental phosphate-bonded investment materials that are used to build, sinter, cast, and press these types of restorations.7,15,16 When fabricating metal-free feldspathic ceramic restorations with the refractory die technique, the application and high burning temperature of the ceramic are accomplished in direct contact with dental phosphate-bonded refractory die products. ${ }^{7,15}$ Therefore, the ceramic is subjected to the influence of the investment according to its composition, surface, and physical-chemical properties. ${ }^{17,18}$

Although several studies have analyzed the mechanical properties of refractory phosphatebonded investment materials, ${ }^{16,20-25}$ investment influence on the final color of ceramics remains unclear ${ }^{17,18,26}$ and deserves further investigation. Because color is considered a sensation obtained through proprioceptive mechanisms, and thus considered subjective, standardized colorimetric techniques were developed with the objective of transforming colors in numeric values. ${ }^{8}$ For this aim, the CIE L*a*b system of colors was created, ${ }^{19}$ eliminating inconsistencies inherent in color perception and specification among observers. ${ }^{8}$ This type of evaluation becomes important as the investment/ceramic relationship constitutes the base of the process of manufacturing ceramic restorations and is directly related to the final aesthetic quality of this type of restoration. ${ }^{7,15}$

The aim of this study was to evaluate the influence of investment type on the color of various conventional powder-slurry feldspathic ceramics. The null hypothesis tested assumed that there would be no color alteration in the ceramics for all investments tested.

\section{MATERIALS AND METHODS}

Specimen preparation

An auto-polymerized acrylic resin mold was machined as a master die for the fabrication of multiple specimens and duplicated with an elastic jelly (Duplicator VIPI, Pirassununga, Sao Paulo, Brazil). Four refractory investment materials were tested (Table 1). Each investment was placed into the jelly moulds, obtaining cylindrical refractory dies, with a central depression with a diameter of $11 \mathrm{~mm}$ and thickness of $1.5 \mathrm{~mm}$, where the ceramics were applied and fired, simulating a refractory die for fabrication of ceramic restorations. The investment was removed from the elastic jelly moulds after 1 hour to acquire appropriate resistance.

The investment materials were mixed in a vacuum investor (Model A 300; Polidental, Pelotas, RS, Brazil) with speed time, liquid, and powder proportions recommended by the manufacturers (Table 1). After setting, the refractory dies were placed into a dental laboratory burnout furnace (Model Edgcon 5P; EDG Equipments, São Paulo, Brazil) at room temperature and heated at different rates $\left({ }^{\circ} \mathrm{C} / \mathrm{min}\right)$ according to ceramics manufacturers' instructions (Table 1).

Five feldspathic ceramics shade A3 I $=20$; Table 2) were applied on the refractory dies of the four investment materials according to the manufacturers' recommendations, resulting in 25 refractory dies for each investment, with 5 refractory dies for each ceramic evaluated.

The discs were fired in a ceramic furnace (Titan 99, EDG Equipments Ltda, São Paulo, Brazil). Refractory dies were cooled and manually divested, and the internal surfaces were airborne-particle abraded (Microjet III; EDG Equipments Ltda, São Paulo, Brazil) with 50- $\mu$ m aluminum oxide abrasive (Aluminum Oxide 50; Almet $\mathrm{GmbH}$, Fellbach, Germany). All discs were cleaned with distilled water in an ultrasonic cleanser for 10 minutes. The ceramic discs were coated with silicone polishers (Eve Diapol, EVE - Ernst Vetter GmbH, Pforzheim, Germanyl and glazed according to manufacturers' recommendations.

For the control specimens, five ceramic specimens were fabricated with each ceramic using a 
circular stainless steel matrix, with a diameter of $11 \mathrm{~mm}$ and thickness of $1.5 \mathrm{~mm}$ without contact with any investment material. Specimens were removed from the matrix and placed in the porcelain-firing oven, fired, polished with silicone polishers, and glazed, as previously described.

\section{Color evaluation}

The evaluation of the color parameters was accomplished through the CIE Lab system of colors using a colorimeter (Colour-Guide ${ }^{\circledR}$, BYK-Gardner, Columbia, MD, USA). To simulate the color of an underlying dental structure, a background disc with $30-\mathrm{mm}$ diameter was made with resin composite (Filtek Z-250®, colour A3; 3M-ESPE, St Paul, MN, USA). In the CIE Lab system, the place of a color in the space is defined through 3 coordinates: $L^{*}, a^{*}$, and $b^{*}$. The $L^{*}$ coordinate is a measure of the lightness-darkness of the specimen; therefore, the greater the $L^{*}$, the lighter the specimen. The $a^{*}$ coordinate is a measure of the chroma along the red-green axis. A positive $a^{*}$ relates to the amount of redness, and a negative $a^{*}$ relates to the amount of green of the specimen. The $b^{*}$ coordinate is a measure of the chroma along the yellow-blue axis, where a positive $b^{*}$ relates to the amount of yellowness, and a negative $b^{*}$ relates to the amount of blue of the specimen. The measure of the total difference of color among 2 objects is described by $\Delta \mathrm{E}$. Color differences above 3.7 units are visually detected. The formula used to calculate the $\Delta \mathrm{E}$ was: $\Delta \mathrm{Eab} *$ $=[(\Delta \mathrm{L} *) 2+(\Delta \mathrm{a} *) 2+(\Delta \mathrm{b} *) 2] 1 / 2$. The $\Delta \mathrm{E}$ values are graded as follows: $\Delta \mathrm{E}<1=$ not appreciable, $\Delta \mathrm{E}$ $<2$ = clinically acceptable, $\Delta \mathrm{E}>2$ = clinically unacceptable, and $\Delta \mathrm{E}>3.7$ = clinically unacceptable with very poor match. ${ }^{27-29}$ The L*a*b* color notation of each specimen was measured thrice consecutively, and an average was calculated to give the initial color of all substrates. The formula used to calculate the lightness is: $L^{*}=L^{*} f-L^{*} i$, with $f$ representing the final value of $L^{*}$ and $i$ the initial value of $L^{*}$ (control group).

\section{Statistical analysis}

The null hypothesis assumed no differences on ceramic colors. Statistical analyses were done, with the significance level fixed at $5 \%$, and analyzed by two-way ANOVA, followed by Tukey post hoc test. The influence of the different invest- ments was analyzed on the final color of the ceramic specimens.

\section{RESULTS}

The amount of alterations in $a^{*}, b^{*}$, and $L^{*}$ color parameters resulted in $\Delta \mathrm{E}$ chromatic alterations of the tested ceramics (Table 3). Vision Esthetic ceramic was the only ceramic to present statistically significant differences $(P=.0001)$ in all color parameters $\left(a^{*}, b^{*}\right.$, and $\left.L^{*}\right)$ among the control and investments tested.. The exception for Vision Esthetic ceramic was for the investments Fortune and Vitadurvest for $b^{*}$ and Duravest for $a^{*}$, with no statistical difference ( $P>$.05).

Significant differences were detected for the ceramic Vintage Halo in a* color parameter among the control group and Duravest $(P=.0009)$ and Fortune $(P=.0001)$ investments, with no statistical differences between the two investments. For Vitadur Alpha ceramic, a significant color difference also was found between the control group and Fortune investment $(P=.0029)$ for $L^{*}$ and $b^{*}$ color parameters, and control and Duravest investment ( $P=.008)$ for $b^{*}$ color parameter.

When we considered the control groups alone, without investments, significant differences were detected for both color parameters $a^{*}$ and $b^{*}$ between ceramics IPS Classic and Vitadur Alpha $(P=.0155)$, and IPS Classic and Vintage Halo $(P=$.0015). The same trend also has occurred for Vintage Halo and Vitadur Alpha (P=.0001) and Vintage Halo and Super Porcelain EX-3 ( $P=$.0001). When considering $a^{*}$ values only, comparison between IPS Classic and Super Porcelain EX-3 presented significant differences $(P=.0001)$. Additionally, $b^{*}$ values also were different between IPS Classic and Vision Esthetic ( $P<.0001)$, and Vintage Halo and Vision Esthetic $(P=.0001)$. For $L^{*}$ values, statistically significant differences were found between Vitadur Alpha and Super Porcelain EX-3 $(P=.0526)$, and Vision Esthetic $(P=.0179)$ and Vintage Halo ( $P=.001$ ) (Figures 1, 2, and 3).

\section{DISCUSSION}

There is a concern on the final color of ceramics commonly used for the fabrication of dental veneers, that is, to allow a clinically stable and aesthetic final restoration. The results of this study support the rejection of the null hypothesis because statistical differences were observed in the 
color parameters of the ceramics promoted by the investment materials tested.

In this study, the color of Vision Esthetic was overall influenced by all refractory investments used, resulting in color alterations considered unacceptable, as $\Delta \mathrm{E}$ values were higher than the visually perceptible limit (3.7 units). ${ }^{27-29}$ In general, the ceramic specimens were less red and less yellow because of a decrease in the values of color parameters $a^{*}$ and $b^{*}$, respectively, when compared with the control group. Regarding the lightness variation, the $\Delta \mathrm{L}^{*}$ values for this ceramic were negative (Figure 4), resulting in a darker color. Ceramic specimens of Vintage Halo using Duravest and Fortune were less red considering the small decrease in the $a^{*}$ values when compared with the control group.

Vitadur Alpha underwent significant alterations in $a^{*}$ and $L^{*}$ parameters when Fortune was

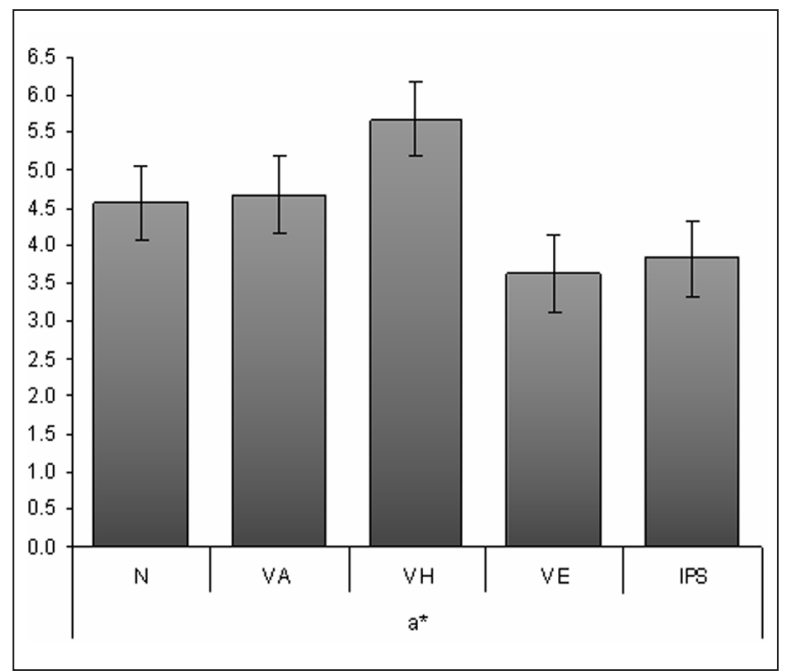

Figure 1. Differences in the $a^{*}$ value for the control groups.

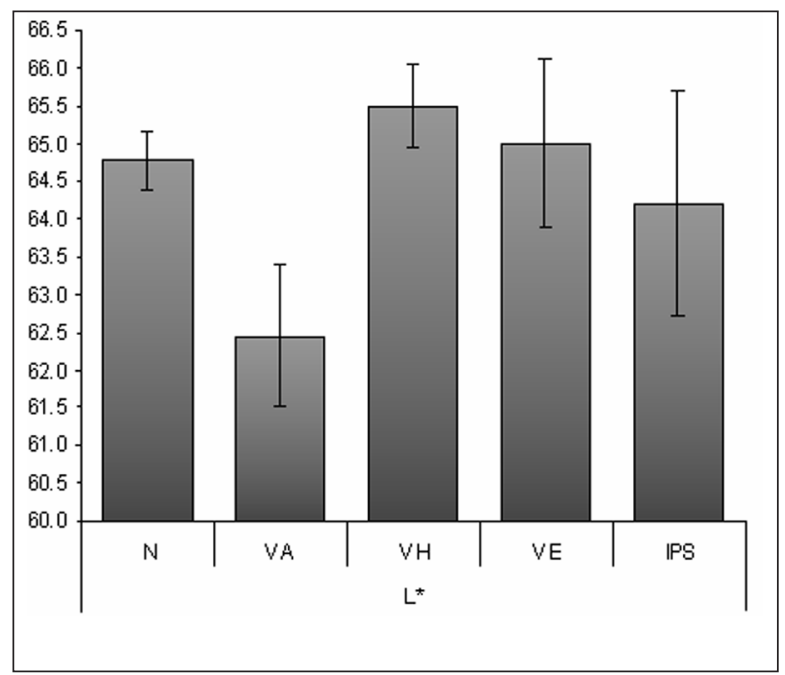

Figure 3. Difference in the $L^{*}$ values for the control groups. used. However, the alterations were restricted to $b^{*}$ values and only when Duravest was used. The use of Fortune resulted in more red and lighter ceramic discs (increase in parameters $a^{*}$ and $L^{*}$, Figure 4) when compared with the control group. On the other hand, Duravest resulted in less yellow ceramic discs (decreased $b^{*}$ values) when compared with the control group. These findings support the idea that the color of ceramic is dependent on the choice of the investment material; therefore, a significant influence of the investment can be expected on the color of the ceramics, resulting in chromatic alterations that may lead to clinically unacceptable results.

Although phosphate-bonded dental casting investment materials have been successfully used in dentistry for more than 40 years, they still present characteristics that remain unclear. ${ }^{24}$ Dental refractory die products are used to construct

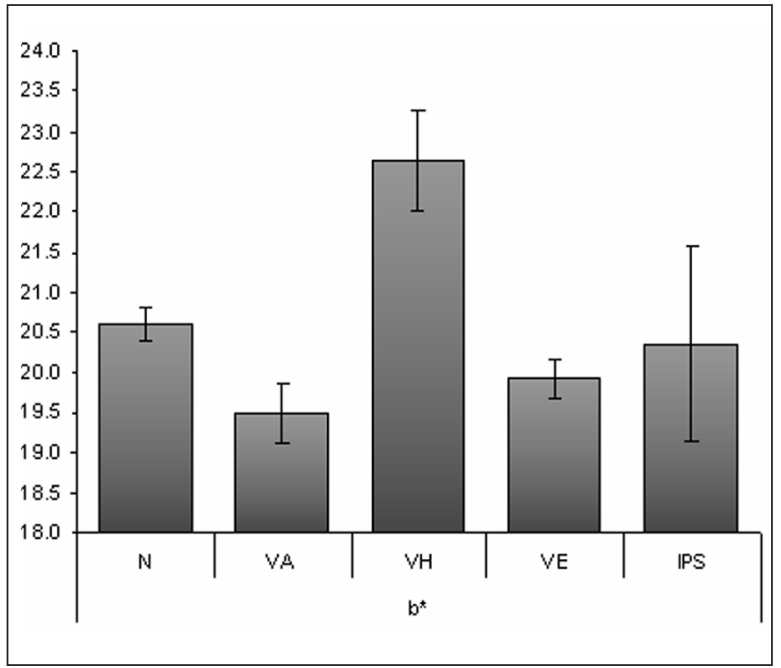

Figure 2. Difference in the $b^{*}$ value for the control groups.

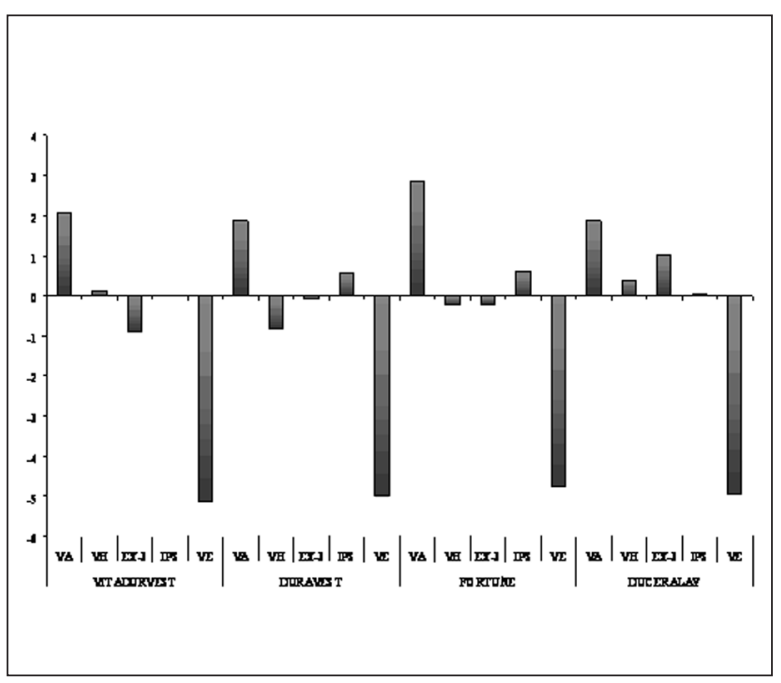

Figure 4. Lightness variation $\left(\Delta L^{*}\right)$ of the ceramics tested. 
models and dies for casting dental alloys and ceramic restorations. ${ }^{16} \mathrm{~A}$ variety of factors have an important role on the appropriate performance of the investment materials that include their setting and thermal expansion, ${ }^{20}$ mould temperature, ${ }^{30}$ air bubbles pores, ${ }^{25}$ casting procedures, ${ }^{31}$ investment technique, ${ }^{15}$ and deformation of investment materials at high temperatures..$^{16}$ In relation to procedures for casting dental alloys, certain defects in the final metal dental alloy superstructures may result from the casting process, such as porosity due to poor filling, shrinkage, or dissolved gases; chemical segregation that results in nonuniform properties due to the physical chemistry of solidification; and contamination due to mould-casting interactions. ${ }^{32}$

Despite the few studies in the literature that evaluated investment influence on ceramic prop- erties, ${ }^{18,26}$ the surface of investment materials are shown to react with the ceramics and affect the surface and shrinkage crystallization, ${ }^{26,33}$ surface roughness, ${ }^{17}$ biaxial flexural strength, and the fit of ceramic restorations.$^{30} \mathrm{~A}$ rough or irregular texture surface will reflect an irregular and diffuse pattern of light, therefore modifying the color of aesthetic restorations. ${ }^{34}$ Surface topography also can influence the color of the ceramic, especially the $L^{*}$ value. ${ }^{35}$ This pattern was verified in Vision Esthetic ceramic, which presented the higher $\Delta \mathrm{E}^{*}$, resulted mainly from the variation of $L^{*}$. Hence, color alterations detected in the ceramics tested in our study can be attributed to possible alterations in ceramic surface topography from the interaction with the refractory investment materials in high temperatures.

Despite all the laboratory and clinical factors

Table 1. Details of the investment materials tested.

\begin{tabular}{|c|c|c|c|c|}
\hline Product name & Manufacturer & Characteristics & Dentin Burn & Glaze \\
\hline \multirow{3}{*}{ Super Porcelain EX-3 (EX-3) } & \multirow{3}{*}{ Noritake, Nishi-Ku Nagoya, Japan } & $\left(\mathrm{Ti}^{\circ} \mathrm{C}\right)$ & 600 & 650 \\
\hline & & $\left(\mathrm{Hr}{ }^{\circ} \mathrm{C} / \mathrm{min}\right)$ & 45 & 50 \\
\hline & & $\left(\mathrm{St}{ }^{\circ} \mathrm{C}\right)$ & 930 & 930 \\
\hline \multirow{3}{*}{ Vision Esthetic (VE) } & \multirow{3}{*}{ Servo dental, Cologne, Germany } & $\left(\mathrm{Ti}^{\circ} \mathrm{C}\right)$ & 400 & 400 \\
\hline & & $\left(\mathrm{Hr}{ }^{\circ} \mathrm{C} / \mathrm{min}\right)$ & 45 & 45 \\
\hline & & $\left(\mathrm{St}{ }^{\circ} \mathrm{C}\right)$ & 770 & 740 \\
\hline \multirow{3}{*}{ Vintage Halo (VH) } & \multirow{3}{*}{ Shofu, Shangai, Japan } & $\left(\mathrm{Ti}{ }^{\circ} \mathrm{C}\right)$ & 450 & 450 \\
\hline & & $\left(\mathrm{Hr}{ }^{\circ} \mathrm{C} / \mathrm{min}\right)$ & 60 & 60 \\
\hline & & $\left(\mathrm{Si}{ }^{\circ} \mathrm{C}\right)$ & 910 & 900 \\
\hline \multirow{3}{*}{ IPS Classic (IPS) } & \multirow{3}{*}{ Ivoclar Vivadent, Liechtenstein, Germany } & $\left(\mathrm{Ti}{ }^{\circ} \mathrm{C}\right)$ & 403 & 403 \\
\hline & & $\left(\mathrm{Hr}{ }^{\circ} \mathrm{C} / \mathrm{min}\right)$ & 60 & 60 \\
\hline & & $\left(\mathrm{Si}{ }^{\circ} \mathrm{C}\right)$ & 920 & 900 \\
\hline \multirow{3}{*}{ Vitadur Alpha (VA) } & \multirow{3}{*}{ Vita Zanhfabrik, Bad Sackingen, Germany } & $\left(\mathrm{Ti}^{\circ} \mathrm{C}\right)$ & 600 & 600 \\
\hline & & $\left(\mathrm{Hr}{ }^{\circ} \mathrm{C} / \mathrm{min}\right)$ & 58 & 58 \\
\hline & & (St $\left.{ }^{\circ} \mathrm{C}\right)$ & 950 & 940 \\
\hline
\end{tabular}

Table 2. Manufacturers' recommendations for initial burning temperature (Ti), heating rate (Hr), and sintering temperature (St) for burning and glazing of the ceramics tested.

\begin{tabular}{|c|c|c|c|c|}
\hline & Vitadurvest & Duravest & Duceralay Superfit & Fortune \\
\hline Water-powder ratio $(\mathrm{ml} \mathrm{g}-1)$ & $6: 30$ & $25: 100$ & $10.5: 30$ & $6.6: 30$ \\
\hline Mixing time (s) & 30 & 60 & 45 & 30 \\
\hline Expansion during prey $\%$ & 0.2 & 0.6 & 0.4 & 0.5 \\
\hline Burnout temperature (oC) & $1200 \max$ & $1200 \max$ & $1100 \max$ & $1100 \max$ \\
\hline Colour & White & White & White & White \\
\hline Batch no. powder & 55042032 & 05012005 & 609000945 & - \\
\hline Batch no. liquid & 55041 & 05012005 & 33089 & - \\
\hline Silica form & Quartz and Cristobalite & Quartz and Cristobalite & Crystalline & $\begin{array}{l}\text { Quartz and } \\
\text { Cristobalite }\end{array}$ \\
\hline Manufacturer & $\begin{array}{c}\text { Vita Zanhfabrik, Spitalgasse } \\
\text { Bad Säckingen } \\
\text { Germany }\end{array}$ & $\begin{array}{c}\text { Polidental, Sao Paulo, } \\
\text { Brazil }\end{array}$ & $\begin{array}{l}\text { Dentsplay, Degudent GmbH, } \\
\text { Hanau-Wolfgang, Germany }\end{array}$ & $\begin{array}{c}\text { IvoclarVivadent, } \\
\text { Amherst NY, } \\
\text { USA }\end{array}$ \\
\hline
\end{tabular}


that can interfere with the final color of ceramic restorations, color differences among ceramics with the same shade but from different manufacturers can occur. ${ }^{8}$ The results of this study corroborates these findings, as significant color differences were detected among the color parameters $a^{*}, b^{*}$, and $L^{*}$ when comparing the controls (no contact with the investment materials) of the five ceramics tested (Table 3). In general, Vintage Halo ceramic used in the control group had the higher a* value (higher red value), whereas Vision Esthetic and IPS Classic ceramics showed the lower a* values, with all ceramics presenting positive values. Regarding parameter $b^{*}$, Vintage Halo ceramic showed the higher $b^{*}$ values (more yellow), whereas Vitadur Alpha and IPS Classic showed the lower $b^{*}$ values (less yellow). When considering ceramics lightness, Super Porcelain EX, Vision Esthetic, and Vintage Halo were the lighter ceramics (higher L* values); however, Vitadur Alpha and IPS Classic were the darkest ceramics, presenting the smaller $L^{*}$ values.
The choice of using a chromatic background was intended to simulate a typical clinical condition in which a chromatic underlying dental structure is present, and a ceramic veneer restoration is planned. ${ }^{36,37}$ The background color of an aesthetic restoration is more or less chromatic, and the thickness of the material can vary. ${ }^{36,38}$ The use of black and white backgrounds has been reported in several studies to standardize the collection of the color data, but this methodology can influence the final color of the ceramic. ${ }^{29}$ Clinically, a composite restoration with a white cement base may appear lighter, more reddish, and more saturated than that with a dark background. ${ }^{38}$ This effect becomes smaller as the thickness of the sample increases. ${ }^{38}$ When increasing resin thickness, the resin may appear darker and less chromatic with a white background and lighter and more chromatic with a black background. ${ }^{39}$ Therefore, a sample may be more or less chromatic depending on its thickness and whether the background is white or black. ${ }^{39}$

Table 3. Mean (SD) color coordinate differences $\left(a^{*}, b^{*}, L^{*}\right.$, and $\Delta E$ ).

\begin{tabular}{|c|c|c|c|c|c|c|}
\hline \multirow[b]{2}{*}{ Color Parameters } & \multirow[b]{2}{*}{ Investments } & \multirow[b]{2}{*}{ Vitadur Alpha } & \multicolumn{3}{|c|}{ Ceramics } & \multirow[b]{2}{*}{$\begin{array}{c}\text { Super Porcelain } \\
\text { EX-3 }\end{array}$} \\
\hline & & & Vintage Halo & Vision Esthetic & IPS Classic & \\
\hline & Vitadurvest & $64.52(0.9)$ & $65.61(0.6)$ & $59.86(0.6)$ & $64.21(1.3)$ & $63.90(0.7)$ \\
\hline & Duravest & $64.33(1.1)$ & $64.33(0.3)$ & $60.00(0.9)$ & $64.21(1.2)$ & $64.71(0.5)$ \\
\hline \multirow[t]{4}{*}{$L^{*}$} & Fortune & $65.32(1.1)$ & $65.27(1.1)$ & $60.24(2.9)$ & $64.82(0.9)$ & $64.58(0.6)$ \\
\hline & Duceralay & $64.33(1.3)$ & $65.87(0.9)$ & $60.05(1.0)$ & $64.27(0.4)$ & $65.30(0.9)$ \\
\hline & Control & $62.45(1.0)$ & $65.48(0.6)$ & $65.00(1.1)$ & $64.21(1.5)$ & $64.78(0.2)$ \\
\hline & Vitadurvest & $4.47(0.1)$ & $5.74(0.3)$ & $2.71(0.5)$ & $3.87(0.1)$ & $4.51(0.2)$ \\
\hline \multirow[t]{5}{*}{$a^{*}$} & Duravest & $4.92(0.2)$ & $4.92(0.2)$ & $3.18(0.1)$ & $4.05(0.4)$ & $4.52(0.3)$ \\
\hline & Fortune & $4.97(0.0)$ & $4.97(0.4)$ & $2.89(0.6)$ & $4.17(0.1)$ & $4.61(0.2)$ \\
\hline & Duceralay & $4.71(0.0)$ & $6.25(0.2)$ & $2.87(0.2)$ & $4.05(0.3)$ & $4.43(0.3)$ \\
\hline & Control & $4.68(0.2)$ & $5.67(0.3)$ & $3.63(0.2)$ & $3.83(0.4)$ & $4.56(0.1)$ \\
\hline & Vitadurvest & $18.46(0.4)$ & $22.83(0.9)$ & $17.58(0.2)$ & $20.40(0.8)$ & $21.49(0.6)$ \\
\hline \multirow[t]{5}{*}{$b^{*}$} & Duravest & $18.01(0.7)$ & $18.01(0.2)$ & $18.18(0.5)$ & $20.28(0.7)$ & $20.28(0.2)$ \\
\hline & Fortune & $17.72(0.9)$ & $17.72(1.1)$ & $17.71(0.4)$ & $20.17(0.4)$ & $19.81(0.2)$ \\
\hline & Duceralay & $18.41(0.8)$ & $21.97(0.3)$ & $17.98(0.2)$ & $20.15(0.6)$ & $20.28(0.6)$ \\
\hline & Control & $19.49(0.4)$ & $22.63(0.6)$ & $19.91(1.1)$ & 20.35 (1.2) & $20.59(0.2)$ \\
\hline & Vitadurvest & $2.40(0.5)$ & $0.54(0.5)$ & 20.89 (1.3) & $1.01(0.9)$ & $1.13(0.5)$ \\
\hline \multirow[t]{3}{*}{$\Delta \mathrm{E}$} & Duravest & $3.40(0.9)$ & $1.17(0.3)$ & $14.55(5.6)$ & $1.02(1.4)$ & $0.22(0.2)$ \\
\hline & Fortune & $5.44(0.5)$ & $1.80(1.0)$ & $17.57(5.2)$ & $0.66(0.6)$ & $0.49(0.3)$ \\
\hline & Duceralay & 2.70 (1.2) & $0.82(0.6)$ & $20.89(4.2)$ & $0.82(0.3)$ & $0.66(0.4)$ \\
\hline
\end{tabular}


To enable the reproduction of indistinguishable restorations with a natural and esthetic aspect, mimicking the natural dentition, besides a perfect anatomy, texture, and marginal adaptation, the perfect final match in color must be achieved. Little consideration has been given to the refractory die materials and the laboratory techniques used during the construction of ceramic restorations. A wide range of chromatic color alterations on veneering ceramics occurring through refractory die methods with investments was found. During the laboratorial process of constructing metal-free ceramic restorations with refractory die techniques, intimate contacts of the investments occur with the ceramic surfaces ${ }^{7,15}$ in high temperatures, contact that varies from some hours to days. Therefore, it is interesting to develop studies that could explore the potential interactions that occur among these materials, especially the ones that can result in alterations of mechanical resistance, surface, and color of ceramics, which directly influence their quality and longevity.

One of the limitations of this study is that there was no analysis of the composition and differences of thermal expansion coefficients among the investment materials and ceramics tested, which could have resulted in a better understanding of their influence on the performance of the unit investment-ceramic during the construction process of a ceramic restorations. In laboratorial practice, ceramics and refractory materials routinely used are usually purchased from independent manufacturers, with some combinations having different thermal expansion coefficients but generally not resulting in differences of performance from matched ceramic and refractory products. ${ }^{40}$ Therefore, further investigations are necessary to evaluate the composition, structure, and performance relationships of these related systems because there are no recommendation protocols of combinations of these materials (ceramics versus investments). ${ }^{40}$ Notwithstanding that such information would be important in understanding the processes involved in the construction of ceramic restorations, a guideline for daily practice for product selection, specifying comparative or standard compliance tests, are mandatory.

\section{CONCLUSIONS}

Within the limitations of this study, the following conclusion can be drawn.

There was a significant influence of the investment refractory materials on the color parameters $a^{*}, b^{*}$, and $L^{*}$ on the ceramics tested, resulting in chromatic alterations unacceptable for some of the ceramic groups tested.

\section{REFERENCES}

1. Sadowsky SJ. An overview of treatment considerations for esthetic restorations: a review of the literature. J Prosthet Dent 2006;96:433-442.

2. Trushkowsky RD, Burgess JO. Complex single-tooth restorations. Dent Clin North Am 2002;46:341-365.

3. Council A. Direct and indirect restorative materials. $J$ Am Dent Assoc 2003;134:463-472.

4. Leinfelder KF. Porcelain esthetics for the 21st century. $J$ Am Dent Assoc 2000;131 Suppl:47S-51S.

5. Kelly JR. Dental ceramics: current thinking and trends. Dent Clin North Am 2004;48:513-530.

6. Cubas GB, Habekost L, Camacho GB, Pereira-Cenci T. Fracture resistance of premolars restored with inlay and onlay ceramic restorations and luted with two different agents. J Prosthodont Res 2011;55:53-59.

7. Matsumura H, Ainda Y, Ishikawa $Y$, Tanoue N. Porcelain laminate veneer restorations bonded with a three-liquid silane bonding agent and a dual-activated luting composite. J Oral Sci 2006;48:261-266.

8. Seghi RR, Johnston WM, O'Brien WJ. Spectrophotometric analysis of colour differences between porcelain systems. J Prosthet Dent 1986;56:35-40.

9. Hammad IA, Stein RS. A qualitative study for the bond and colour of ceramometals: Part II. J Prosthet Dent 1991;65:169-179.

10. O'Brien WJ, Kay KS, Boenke KM, Groh CL. Sources of colour variation on firing porcelain. Dent Mater 1991;7:170173.

11. Jorgenson MW, Goodkind RJ. Spectrophotometric study of five porcelain shades relative to the dimensions of colour, porcelain thickness, and repeated firings. J Prosthet Dent 1979;42:96-105.

12. Barghi N. Colour and glaze: effects of repeated firings. $J$ Prosthet Dent 1982;47:393-395.

13. Raptis NV, Michalakis KX, Hirayama H. Optical behavior of current ceramic systems. Int J Periodontics Restorative Dent 2006;26:31-41. 
14. Okubo SR, Kanawati A, Richards MW, Childress S. Evaluation of visual and instrument shade matching. $J$ Prosthet Dent 1998;80:642-648.

15. Magne $P$, Cascione D. Influence of post-etching cleaning and connecting porcelain on the microtensile bond strength of composite resin to feldspathic porcelain. $J$ Prosthet Dent 2006;96:354-361.

16. Juszczyk AS, Radford DR, Curtis RV. Deformation of phosphate-bonded investment materials at elevated temperatures. Dent Mater 2007;23:579-585.

17. Johnson A, Noort R van, Hatton PV, Walsh JM. The effect of investment material and ceramming regime on the surface roughness of two castable glass-ceramic materials. Dent Mater 2003;19:218-225.

18. Taskonak B, Anusavice K.J, Mecholsky JJ Jr. Role of investment interaction layer on strength and toughness of ceramic laminates. Dent Mater 2004;20:701-708.

19. CIE. Colourimetry: official recommendations of the International Commission on Illumination. Paris: Commission Internationale de l'Èclairage [International Commission on Illumination], 1976; CIE No. 15 (E-1.3.1).

20. Soo S, Palmer R, Curtis RV. Measurement of the setting and thermal expansion of dental investments used for the superplastic forming of dental implant superstructures. Dent Mater 2001;17:247-252.

21. Hutton JE, Marshall GW. The expansion of phosphate bonded investments: Part I--Setting expansion. J Prosthet Dent 1993;70:121-125.

22. Luk WK, Darvell BW. Effect of burnout temperature on strength of gypsum-bonded investments. Dent Mater 2003; 19:552-557.

23. Hsu HC, Kikuchi H, Yen SK, Nishiyama M. Evaluation of different bonded investments for dental titanium casting. $J$ Mater Sci Mater Med 2005;16:821-825.

24. Scrimgeour SN, Chudek JA, Lloyd CH. The determination of phosphorus containing compounds in dental casting investment products by 31P solid-state MAS-NMR spectroscopy. Dent Mater 2007;23:415-424.

25. Juszczyk AS, Radford DR, Curtis RV. Sensitivity of a disc rupture strength test to air bubble pores in phosphatebonded investment materials at elevated temperatures. Dent Mater 2002;18:255-262.

26. Bandyopadhyay-Ghosh S, Reaney IM, Johnson A, HurrellGillingham K, Brook IM, Hatton PV. The effect of investment materials on the surface of cast fluorcanasite glasses and glass-ceramics. J Mater Sci Mater Med 2008;19:839-846.

27. Seghi RR, Johnston WM, O'Brien W.J. Performance assessment of colourimetric devices on dental porcelains. $J$ Dent Res 1989;68:1755-1759.
28. Johnston WM, Kao EC. Assessment of appearance match by visual observation and clinical colourimetry. J Dent Res 1989;68:819-822

29. Barath VS, Faber FJ, Westland S, Niedermeier W. Spectrophotometric analysis of all-ceramic materials and their interaction with luting agents and different backgrounds. Adv Dent Res 2003;17:55-60.

30. Johnson A, Shareef MY, Walsh JM, Hatton PV, Noort R van, Hill RG. The effect of casting conditions on the biaxial flexural strength of glass-ceramic materials. Dent Mater 1998; 14:412-416.

31. Viennot S, Lissac M, Malquarti G, Dalard F, Grosgogeat B. Influence of casting procedures on the corrosion resistance of clinical dental alloys containing palladium. Acta Biomater 2006;2:321-330.

32. Atwood RC, Lee PD, Curtis RV. Modeling the surface contamination of dental titanium investment castings. Dent Mater 2005;21:178-186.

33. Yamamoto T, Takamizu M, Kohno A. Influence of residual surface investment material on crystallization shrinkage of a mica-based glass-ceramic. Dent Mater 2002;18:336-342.

34. Lee YK, Lim BS, Kim CW. Effect of surface conditions on the colour of dental resin composites. J Biomed Mater Res 2002;63:657-663.

35. Kim IJ, Lee YK, Lim BS, Kim CW. Effect of surface topography on the colour of dental porcelain. J Mater Sci Mater Med 2003;14:405-409.

36. Christensen GJ. Facing the challenges of ceramic veneers. J Am Dent Assoc 2006;137:661-664.

37. Christensen GJ. Ceramic veneers: state of the art, 1999. J Am Dent Assoc 1999;130:1121-1123.

38. Miyagawa Y, Powers JM. Prediction of color of an esthetic restorative material. J Dent Res 1983;62:581-584.

39. Powers JM, Dennison JB, Lepeak PJ. Parameters that affect the color of direct restorative resins. J Dent Res 1978;57:876-880.

40. Wildgoose DG, Winstanley RB, Noort R van. The laboratory construction and teaching of ceramic veneers: a survey. $J$ Dent 1997;25:119-123. 